\title{
PUBLIC SERVICE QUALITY AND CITIZEN-CLIENT'S SATISFACTION IN LOCAL MUNICIPALITIES. A CASE STUDY: MUNICIPALITY OF TETOVO
}

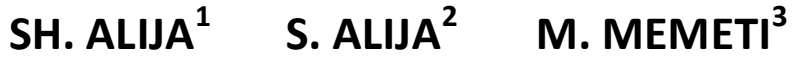

\begin{abstract}
Assessing the effects of compensation for construction permits for residential and economic buildings in the urban part of Tetovo, the establishment of professional teams for the legalization of illegal buildings and the development of electronic services, on local economic development (LED) of the municipality of Tetovo. For analysing the data generated by the questionnaires, SPSS was used, as a method for testing the hypotheses of the study. The reduction of the compensation for construction, the creation of professional teams for the legalization of illegal buildings, the development of electronic services contribute to the increase in the satisfaction of the residents of the municipality of Tetovo, stimulate economic activity and increase fiscal revenues.
\end{abstract}

Key words: fiscal decentralization, compensation for construction permits, professional teams for the legalization of illegal buildings, and development of electronic services.

\section{Introduction}

In the second half of the twentieth century, decentralization, as a process of transfer of responsibilities from central to local government, plays a key role in the field of public finance. OECD countries are considered as an example of how to implement the decentralization process, and the delegation of a wide range of competencies and fiscal capabilities to their local authorities, respectively. The fiscal autonomy of local selfgovernment units is a precondition for economic freedom. If the quality of public goods

\footnotetext{
${ }^{1}$ South East European University, Republic of North Macedonia, s.alija@seeu.edu.mk, ORCID ID: 00000003-1898-8072

${ }^{2}$ South East European University, Republic of North Macedonia, s.aliji@seeu.edu.mk, ORCID ID: 0000-00020355-731X

${ }^{3}$ South East European University, Republic of North Macedonia, m.memeti@seeu.edu.mk
} 
and services does not improve, then taxpayers are not interested in a high level of fiscal decentralization. Thus, fiscal policy measures taken by local governments represent the main force responsible for the competitive business environment and economic wellbeing in both developed and transition countries (Pasichnyi et al., 2019).

\subsection{Objectives of the study}

This study analyses and reveals the impact that the compensation for construction permits for residential and economic buildings in the urban part of Tetovo, the legalization of illegal facilities, the property tax rates, the turnover and economic services have on the economic development of the municipality of Tetovo. Thus, the paper will try to assess:

- if the compensation for construction permits for residential and economic buildings in the urban part of Tetovo should be reduced to be stimulant for new construction;

- if the establishment of professional teams for the legalization of illegal facilities will affect citizens' satisfaction, will stimulate economic activity and will increase fiscal revenues;

- if the property tax and turnover tax rates should be reduced by increasing the market value as a basis for calculating fiscal revenues;

- if the implementation of electronic utilities will boost citizens' satisfaction, reduce over-employment in the municipality and reduce operating budget costs.

\subsection{Hypothesis of the study}

This study will also attempt to answer the following hypotheses:

1. The compensation for construction permits for residential and economic buildings in the urban part of Tetovo should be reduced to be stimulant for new construction.

2. The establishment of professional teams for the legalization of illegal facilities will affect citizens' satisfaction, will stimulate economic activity and will increase fiscal revenues.

3. Property tax and turnover tax rates should be reduced by increasing the market value as a basis for calculating fiscal revenues.

4. The implementation of electronic utilities will boost citizen satisfaction, reduce overemployment in the municipality and reduce operating budget costs.

\section{Literature Review}

The provision of public services, namely the provider/customer relationship is complex and direct because the compensation is not directly related with the service received, and so the citizens (costumers) control is weakened due to the limitation of choice consequent of monopolistic provision. Further, the provider's ability to supply is determined by budgetary funding outside its direct control (Humphreys, 1988). In 
defining and delivering good quality municipal services, the crucial thing is to understand exactly the needs of citizen's and their feedback, which provides valuable insight into how well the municipal authority meets the citizen's needs.

The quality of municipal services is measured through the level of citizens' satisfaction and by the extent of variation in the distribution of service satisfaction within a community (including the level of satisfaction related to the public transport, management of primary and secondary schools, maintenance of local roads, sewerage, and public hygiene, etc). The most popular model for measuring service quality is the SERVQUAL, which is not only used in marketing, but also in other sectors including government institutions, as well as the SEM model, system dynamics (SD) model etc.

There are researches that deeply believe that service quality leads to satisfaction of citizen's and otherwise. The assertion that service quality is the cause of satisfaction is empirically supported by the Mokhlis, Aleesa and Mamat (Mokhlis, et.al, 2011), during the examination of quality of municipal services provided by local government in southern Thailand. The latter, by using descriptive statistics, exploratory factor analysis, Pearson correlation and step-wise multiple regression ascertained that the five dimensions of SERVQUAL represented a valid instrument for measuring municipal service quality, namely tangibility, empathy, assurance, and responsiveness significantly predicted citizen satisfaction in southern Thailand.

Also, Zagorie and Rozenes (R. Zagorie \& Sh. Rozenes, 2017), during the examination of the quality of municipal services, identified the most important service quality dimensions, which determine citizen's satisfaction and the ways of improving, within an Izrael town founded that the dimensions of SERVQUAL represented a valid instrument in measuring municipal overall service quality, respectively three service quality dimensions, reliability, empathy and responsiveness significantly predicted citizens satisfaction.

The group of authors Mbassi, Mbarga, Ndeme (Mbassi, et.al, 2019), based on the revisited SERVQUAL model for identification, description and evaluation of the link between public service quality and citizen-client satisfaction in local municipalities, found that the aspects of service quality do not contribute identically to users 'satisfaction.

Further, El-Bassiouni, Madi, Zoubeidi, Hassan (El-Bassiouni, et.al, 2012), in developing customer satisfaction indices for the services provided by inspectors in certain departments of Al-Ain Municipality, the United Arab Emirates, by using the customer satisfaction models with SERVQUAL survey input, found that the customer satisfaction indices and scores of customers trust were in the mid-eighties, indicating high levels of satisfaction and client trust, although there is room for improvement.

Gumus and Koleoglu (M. Gumus, N. Koleoglu, 2002), by adapting the SERVQUAL and SERVPERF partly as instruments for measuring the quality of municipal services, analysed the service quality level of Canakkale municipality in Turkey. Results showed that the overall quality and satisfaction levels were average. Due to this, the education 
for managers and service personnel was the main proposal for the improvement in service quality and satisfaction.

Taking into consideration the findings in this area by using mainly the SERVQUAL instrument for measuring the relation between quality services and citizens satisfaction, this study using Structural equation modeling (SEM), a multivariate technique for testing and evaluating multivariate causal relationships, analyses the correlation between service quality, management, planning and satisfaction of the citizen's of the municipality of Tetovo, in North Macedonia, respectively how the provision of quality municipal services, service management and planning increase the citizens satisfaction.

\section{Methodology}

To answer our research questions and validate the study hypotheses, we designed a questionnaire divided into three parts, including:

- demographic data (first part)

- questions related to citizens' satisfaction (second part ), and

- questions that sought the opinion of citizens on aspects connected to improving the utilities and increasing the fiscal revenues.

The questionnaire was organized online in early 2020 with the citizens of the municipality of Tetovo. The database contains 312 complete responses, in which participants reported subjectively on their attitudes and perceptions.

Table 1 provides detailed information on the demographic characteristics of the citizens who participated in this study. This shows that the participation of women is higher, $53.8 \%$ respectively, compared to men, with $46.2 \%$. In terms of age and education, $51.9 \%$ were aged $18-24$, while $38.5 \%$ were participants who completed university level and $35.9 \%$ high school. Regarding the place of residence, $51.9 \%$ belong to the urban area and $48.1 \%$ to the rural area, while in terms of the number of family members, most of the respondents belong to families with five and four members, $32.7 \%$ and $26.3 \%$ respectively.

Participants' demographic information

Table 1

\begin{tabular}{lll}
\hline Variables & Values & Percentage \\
\hline Gender & Male & 46.2 \\
& Female & 53.8 \\
Age & $18-24$ years old & 51.9 \\
& $25-39$ years old & 39.7 \\
& $40-59$ years old & 5.1 \\
Head of family's education & Pr-69 years old & 3.2 \\
& Primary education & 25.6 \\
& Secondary education & 35.9 \\
& Higher education & 38.5
\end{tabular}




\begin{tabular}{lll}
\hline Variables & Values & Percentage \\
\hline Area & Urban areas & 51.9 \\
& Rural areas & 48.1 \\
Number of family members & Two members & 1.3 \\
& Three members & 8.3 \\
& Four members & 26.3 \\
& Five members & 32.7 \\
& Six members & 15.4 \\
& More than six members & 16.0 \\
Monthly household income & Less than 100 Euros & 3.2 \\
& $100-200$ Euro & 9.0 \\
& $300-400$ Euro & 13.5 \\
& $400-500$ Euro & 11.5 \\
& $500-600$ Euro & 9.6 \\
& $600-800$ Euro & 9.6 \\
& $800-1000$ Euro & 9.0 \\
& Over 1000 Euros & 34.6 \\
\hline
\end{tabular}

\section{Results}

\subsection{The assessment of citizens towards some municipal services}

In this section, we analyse the satisfaction of citizens towards some municipal services. Table 2 shows the assessment of citizens with respect to some services, where most citizens are not at all satisfied and little satisfied with a high percentage, versus citizens moderately satisfied, satisfied and very satisfied.

It is clear that the highest level of responses with not at all satisfied and little satisfied people, over $70 \%$ respectively, had to do with the condition and maintenance of roads, sidewalks and parking lots, as well as sewerage and public hygiene. Over $60 \%$ of the most dissatisfied and less satisfied responses were related to urban and rural planning, land use, waste and garbage disposal, local road maintenance, high prices and tax payment procedures, public transport, selection of local municipal staff etc.

Over $50 \%$ of the answers with not at all satisfied and little satisfied respondents had to do with the support of initiative sports and cultural activities, the greening of areas designed for greenery along the road, while the rest were under $50 \%$.

Overview of Respondents' Satisfaction

Table 2

\begin{tabular}{|c|c|c|c|c|c|c|c|}
\hline \multicolumn{6}{|c|}{ Percentage of respondents } & \multicolumn{2}{|c|}{ Mean score } \\
\hline $\begin{array}{l}\text { P9. How do you rate the work of } \\
\text { the following services }\end{array}$ & $\begin{array}{l}\text { Not at } \\
\text { all } \\
\text { satis- } \\
\text { fied }\end{array}$ & $\begin{array}{l}\text { Slight } \\
\text { ly } \\
\text { satis- } \\
\text { fied }\end{array}$ & $\begin{array}{l}\text { Moder- } \\
\text { ately } \\
\text { satisfied }\end{array}$ & $\begin{array}{l}\text { Satis- } \\
\text { fied }\end{array}$ & $\begin{array}{l}\text { Very } \\
\text { satis- } \\
\text { fied }\end{array}$ & $\begin{array}{c}\text { Mea } \\
\mathrm{n}\end{array}$ & $\begin{array}{l}\text { Std. } \\
\text { Devia- } \\
\text { tion }\end{array}$ \\
\hline Management of primary and & 14.1 & 28.8 & 25.6 & 25.0 & 6.4 & 2.8 & 1.2 \\
\hline
\end{tabular}




\begin{tabular}{|c|c|c|c|c|c|c|c|}
\hline \multirow[b]{2}{*}{$\begin{array}{l}\text { P9. How do you rate the work of } \\
\text { the following services }\end{array}$} & \multicolumn{5}{|c|}{ Percentage of respondents } & \multicolumn{2}{|c|}{ Mean score } \\
\hline & $\begin{array}{l}\text { Not at } \\
\text { all } \\
\text { satis- } \\
\text { fied }\end{array}$ & $\begin{array}{l}\text { Slight } \\
\text { ly } \\
\text { satis- } \\
\text { fied }\end{array}$ & $\begin{array}{c}\text { Moder- } \\
\text { ately } \\
\text { satisfied }\end{array}$ & $\begin{array}{l}\text { Satis- } \\
\text { fied }\end{array}$ & $\begin{array}{l}\text { Very } \\
\text { satis- } \\
\text { fied }\end{array}$ & $\begin{array}{c}\text { Mea } \\
\mathrm{n}\end{array}$ & $\begin{array}{l}\text { Std. } \\
\text { Devia- } \\
\text { tion }\end{array}$ \\
\hline $\begin{array}{l}\text { Initiation of sports activities and } \\
\text { their support }\end{array}$ & 25.0 & 30.1 & 19.9 & 19.9 & 5.1 & 2.5 & 1.2 \\
\hline $\begin{array}{l}\text { Initiation of cultural activities } \\
\text { and their support }\end{array}$ & 29.5 & 28.8 & 17.9 & 19.9 & 3.8 & 2.4 & 1.2 \\
\hline $\begin{array}{l}\text { Maintenance of roads, } \\
\text { sidewalks and parking lots }\end{array}$ & 46.8 & 24.4 & 9.0 & 17.3 & 2.6 & 2.0 & 1.2 \\
\hline Sewerage and public hygiene & 46.2 & 25.0 & 10.9 & 11.5 & 6.4 & 2.1 & 1.3 \\
\hline $\begin{array}{l}\text { Urban and rural planning, land } \\
\text { use }\end{array}$ & 40.4 & 22.4 & 16.0 & 12.2 & 9.0 & 2.3 & 1.3 \\
\hline $\begin{array}{l}\text { Waste and garbage disposal, as } \\
\text { well as similar sanitary activities }\end{array}$ & 38.5 & 23.1 & 14.7 & 16.0 & 7.7 & 2.3 & 1.3 \\
\hline Fire and emergency services & 10.9 & 20.5 & 34.6 & 17.3 & 16.7 & 3.1 & 1.2 \\
\hline $\begin{array}{l}\text { Maintenance and operation of } \\
\text { the wholesale and retail market }\end{array}$ & 14.7 & 32.7 & 22.4 & 20.5 & 9.6 & 2.8 & 1.2 \\
\hline Management of municipal funds & 37.8 & 25.0 & 14.1 & 17.9 & 5.1 & 2.3 & 1.3 \\
\hline Maintenance of local roads & 37.2 & 25.6 & 14.1 & 16.7 & 6.4 & 2.3 & 1.3 \\
\hline $\begin{array}{l}\text { Greening of redesigned areas } \\
\text { for greenery along the road }\end{array}$ & 34.0 & 25.6 & 16.7 & 15.4 & 8.3 & 2.4 & 1.3 \\
\hline $\begin{array}{l}\text { High prices and procedures for } \\
\text { paying taxes }\end{array}$ & 41.0 & 21.2 & 15.4 & 16.7 & 5.8 & 2.3 & 1.3 \\
\hline $\begin{array}{l}\text { Preserving the ground, plants } \\
\text { and animals }\end{array}$ & 35.3 & 25.6 & 15.4 & 15.4 & 8.3 & 2.4 & 1.3 \\
\hline Public transport & 44.2 & 19.9 & 12.2 & 13.5 & 10.3 & 2.3 & 1.4 \\
\hline Selection of local municipal staff & 37.8 & 28.2 & 14.1 & 10.9 & 9.0 & 2.3 & 1.3 \\
\hline Public street lighting & 25.0 & 24.4 & 22.4 & 16.7 & 11.5 & 2.7 & 1.3 \\
\hline
\end{tabular}

To analyse the utilities of the municipality of Tetova, we raised four hypotheses at the beginning of the study, regarding the prices of construction permits, the legalization of illegal buildings, property tax, turnover tax rates and the implementation of electronic municipal services. In what follows, we present the acceptance or rejection of the study hypotheses.

To validate the first hypothesis: Compensation for construction permits of residential and economic buildings in the urban part of Tetovo should be reduced to be stimulant for new construction, we assumed that the proportion of citizens who declare that the construction permits of residential and economic buildings in the urban part of Tetovo should be reduced is more than $75 \%$.

$$
\begin{aligned}
& \mathbf{H}_{\mathbf{0}}: p \leq 0.75 \\
& \mathbf{H}_{\mathbf{a}}: \mathbf{p}>0.75
\end{aligned}
$$

To validate the second hypothesis: The creation of professional teams for the legalization of illegal objects will cause satisfaction to citizens, stimulate economic 
activity and increase fiscal revenues, we assumed that the proportion of citizens who declare the creation of professional teams for legalization of illegal facilities will cause satisfaction to citizens, stimulate economic activity and increase fiscal revenues is more than $90 \%$.

$$
\begin{aligned}
& \mathbf{H}_{0}: p \leq 0.90 \\
& \mathbf{H}_{\mathbf{a}}: p>0.90
\end{aligned}
$$

To validate the third hypothesis: Property tax and turnover tax rates should be reduced by increasing the market value as a basis for calculating fiscal revenues, we assumed that the proportion of citizens who declare that property tax rates and tax on turnover should be reduced by increasing the market value as the basis for calculating fiscal revenue is more than $95 \%$.

$$
\begin{aligned}
& \mathbf{H}_{0}: p \leq 0.95 \\
& \mathbf{H}_{\mathbf{a}}: \mathbf{p}>0.95
\end{aligned}
$$

To validate the fourth hypothesis: The implementation of e-utilities will boost citizen satisfaction, reduce over-employment in the municipality and reduce operating budget costs, we assumed that the proportion of citizens who declare that the implementation of e-services will boost citizen satisfaction, reduce over-employment in the municipality and reduce operating budget costs is more than $95 \%$.

\begin{tabular}{|c|c|c|c|c|c|c|c|}
\hline \multicolumn{8}{|l|}{ One-Sample Test } \\
\hline \multirow[t]{2}{*}{ Hypotheses } & \multirow[t]{2}{*}{$\begin{array}{l}\text { Test } \\
\text { Value }\end{array}$} & \multirow[t]{2}{*}{$\begin{array}{llll}T & \end{array}$} & \multirow[t]{2}{*}{ Df } & \multirow[t]{2}{*}{$\begin{array}{l}\text { Sig. } \\
(2- \\
\text { tailed) }\end{array}$} & \multirow[t]{2}{*}{$\begin{array}{c}\text { Mean } \\
\text { Difference }\end{array}$} & \multicolumn{2}{|c|}{$\begin{array}{l}95 \% \text { Confidence } \\
\text { Interval of the } \\
\text { Difference }\end{array}$} \\
\hline & & & & & & Lower & Upper \\
\hline $\begin{array}{l}\text { Citizens' opinion on } \\
\text { construction taxes }\end{array}$ & 0.75 & 14.794 & 155 & 0 & 1.08333 & 0.9387 & 1.228 \\
\hline $\begin{array}{l}\text { Do you think that the } \\
\text { creation of professional } \\
\text { teams for the } \\
\text { legalization of illegal } \\
\text { facilities will have an } \\
\text { effect on the satisfaction } \\
\text { of citizens, will stimulate } \\
\text { economic activity and } \\
\text { increase fiscal revenues? }\end{array}$ & 0.9 & 10.732 & 155 & 0 & 0.75385 & 0.6151 & 0.8926 \\
\hline $\begin{array}{l}\text { Do you think that } \\
\text { property tax and } \\
\text { turnover tax rates should }\end{array}$ & 0.95 & 10.336 & 155 & 0 & 0.72308 & 0.5849 & 0.8613 \\
\hline
\end{tabular}

$$
\begin{aligned}
& \mathbf{H}_{\mathbf{0}}: p \leq 0.95 \\
& \mathbf{H}_{\mathbf{a}}: \mathbf{p}>0.95
\end{aligned}
$$

One-Sample Test

Table 3 


\begin{tabular}{|c|c|c|c|c|c|c|c|}
\hline \multicolumn{8}{|l|}{ One-Sample Test } \\
\hline \multirow[t]{2}{*}{ Hypotheses } & \multirow[t]{2}{*}{$\begin{array}{c}\text { Test } \\
\text { Value }\end{array}$} & \multirow[t]{2}{*}{$\mathbf{T}$} & \multirow[t]{2}{*}{ Df } & \multirow[t]{2}{*}{$\begin{array}{l}\text { Sig. } \\
(2- \\
\text { tailed) }\end{array}$} & \multirow[t]{2}{*}{$\begin{array}{c}\text { Mean } \\
\text { Difference }\end{array}$} & \multicolumn{2}{|c|}{$\begin{array}{l}\text { 95\% Confidence } \\
\text { Interval of the } \\
\text { Difference }\end{array}$} \\
\hline & & & & & & Lower & Upper \\
\hline $\begin{array}{l}\text { be reduced by increasing } \\
\text { the market value as a } \\
\text { basis for calculating } \\
\text { fiscal revenues? }\end{array}$ & & & & & & & \\
\hline $\begin{array}{l}\text { Do you think that the } \\
\text { implementation of } \\
\text { electronic utilities will } \\
\text { increase citizen } \\
\text { satisfaction, reduce } \\
\text { over-employment in the } \\
\text { municipality and reduce } \\
\text { operating budget costs? }\end{array}$ & 0.95 & 13.54 & 155 & 0 & 1.35128 & 1.1541 & 1.5484 \\
\hline
\end{tabular}

By placing the data in the dialog table of the SPSS program, with level of importance $\alpha=0.05$, in Table 3 we have:

- In the second hypothesis, it turns out that the statistic of the $T$ test is $t_{\alpha}=10.73$ and the calculated $p$-value is 0.000 . Since $p=0.000<0.05$ and $t_{\alpha}=10.73>1.645=t_{0.05}$ hypothesis $\mathbf{H}_{0}$ is rejected in favour of hypothesis $\mathbf{H}_{\mathbf{a}}$.

The $\mathbf{H}_{\mathbf{a}}$ hypothesis is accepted, respectively the proportion of citizens who think that the compensation for construction permits of residential and economic buildings in the urban part of Tetovo should be reduced to be stimulant for new construction results in more than $75 \%$. The confidence interval is [0.94, 1.23].

- In the second hypothesis, it turns out that the statistic of the T test is $\mathrm{t}_{\alpha}=10.73$ and the calculated $\mathrm{p}$-value is 0.000 . Since $\mathrm{p}=0.000<0.05$ and $\mathrm{t}_{\alpha}=10.73>1.645=\mathrm{t}_{0.05}$ hypothesis $\mathbf{H}_{0}$ is rejected in favour of hypothesis $\mathbf{H}_{\mathbf{a}}$.

The $\mathbf{H}_{\mathbf{a}}$ hypothesis is accepted, respectively the proportion of citizens who think that the creation of professional teams for the legalization of illegal objects will cause satisfaction to citizens, will stimulate economic activity and increase fiscal revenues resulting in more than $90 \%$. The confidence interval is $[0.62,0.89]$.

- In the third hypothesis, it turns out that the statistic of the $T$ test is $t \alpha=10.34$ and the calculated $p$-value is 0.000 . Since $p=0.000<0.05$ and $t \alpha=10.34>1.645=t 0.05$ hypothesis $\mathbf{H}_{0}$ is rejected in favour of hypothesis $\mathbf{H}_{\mathbf{a}}$.

The $\mathbf{H}_{\mathrm{a}}$ hypothesis is acceptable, which means that the proportion of citizens who think that property tax and turnover tax rates should be reduced by increasing the market value as a basis for calculating fiscal revenues is more than $95 \%$. The confidence interval is $[0.58,0.86]$. 
- In the third hypothesis, it turns out that the statistic of the $T$ test is $t_{\alpha}=13.54$ and the calculated $p$-value is 0.000 . Since $p=0.000<0.05$ and $t_{\alpha}=13.54>1.645=t_{0.05}$ hypothesis $\mathbf{H}_{0}$ is rejected in favour of hypothesis $\mathbf{H}_{\mathrm{a}}$.

So, even in the case of the last hypothesis, we find that the $\mathbf{H}_{\mathbf{a}}$ hypothesis is accepted, respectively the proportion of citizens who think that the implementation of electronic municipal services will increase citizen satisfaction, reduce redundancy in the municipality and reduce operating budget costs is more than $95 \%$. The confidence interval is [1.15, 0.1.55].

\section{Conclusions}

- The process of fiscal decentralization in the Western Balkan countries, including North Macedonia, has encountered serious obstacles, causing a low level of local economic development.

- Ineffective implementation of the law on unequal regional development has deepened local and regional inequalities in all local self-government units, and municipalities, respectively.

- Reducing the compensation for construction permits for residential and economic buildings in the urban part of Tetovo is considered to stimulate new construction, while the creation of professional teams for the legalization of illegal buildings on the one hand increases the satisfaction of residents of Tetovo, while on the other hand it stimulates economic activity and increases fiscal revenues.

- The implementation of electronic municipal services affects the increase of the inhabitants' satisfaction in the municipality of Tetova, and consequently it will reduce the redundant employees of the municipality and the operating budget costs.

\section{References}

Boyle, R., 2020. Measuring Customer Satisfaction in Local Government. Local Government Research Series, no.19.

El-Bassiouni, M.I. et al., 2012. Developing customer satisfaction indices using SERVQUAL sampling surveys : A case study of Al-Ain municipality inspectors. Journal of Economic and Administrative Sciences, 28 (2), pp.98-108.

Gumus, M., Koleoglu, N., 2002. Factor analysis on service attributes of Canakkale municipality. The TQM Magazine, pp. 373-375.

Humphreys, P. C., 1988. Improving Public Service Delivery. Ireland: Institute of Public Administration. 
Mbassi, J.C. et al., 2019. Public Service Quality and Citizen-Client's Satisfaction in Local Municipalities . Journal of Marketing Development and Competitiveness, 13 (3).

Mokhlis, S. et al., 2011. Municipal Service Quality and Citizen Satisfaction in Southern Thailand . Journal of Public Administration and Governance, 1 (1), pp. 122-137.

Oates, W. E., 1972. Fiscal Federalism. New York: Harcourt, Brace, Jovanovich.

Zagorie, R. \& Rozenes, Sh., 2017. How to increase citizen satisfaction within municipal services: an Israeli case study. Int. J. Society Systems Science, pp. 301-19. 